Bangladesh J. Zool. 42(2): 251-259, 2014

\title{
NUTRIENT CONTENTS OF SOME POPULAR FRESHWATER AND MARINE FISH SPECIES OF BANGLADESH
}

\author{
Maria Zaman, M. Niamul Naser*,1, Abu Tareq Mohammad Abdullah \\ and Nasima Khan \\ Institute of Food Science and Technology, Bangladesh Council of Scientific and \\ Industrial Research, Dhanmondi, Dhaka 1205, Bangladesh
}

\begin{abstract}
An investigation was carried out on the proximate and mineral contents of widely consumed freshwater small indigenous species (SIS), culture and marine fish species of Bangladesh. Proximate composition (crude protein, fat, ash, moisture, carbohydrate and energy) and selected mineral ( $\mathrm{Ca}, \mathrm{K}, \mathrm{Na}, \mathrm{Mg}$, $\mathrm{Fe}, \mathrm{Zn}$ and $\mathrm{Mn}$ ) contents were determined eighteen locally available fish species of Bangladesh. Considering proximate composition high protein fishes are Thai Sarpunti $17.5 \pm 0.15 \%$, Rui $16.82 \% \pm 0.02$; high fat fishes are Thai Pangus 10.03 $\pm 0.1 \%$, Thai Sarpunti 9.38 $\pm 0.37 \%$; high Ash contents in Poa $4.78 \pm 0.92 \%$, Ganges Chapila $3.96 \pm 0.51 \%$, Thai Sarpunti $3.31 \pm 0.14 \%$; high energy found in Thai Sarpunti $157.02 \pm 2.61 \mathrm{Kcal} / \mathrm{g}$ and Thai Pangus $151.59 \pm 2.71 \mathrm{Kcal} / \mathrm{g}$. Considering mineral compositions, Ca rich fishes are Punti $1984.32 \pm 1.1 \mathrm{mg}$, Mola $1267 \pm 2.2 \mathrm{mg}$, Dhela $1717.8 \pm 3.1 \mathrm{mg}$, Chapila $1100.6 \pm 1.21 \mathrm{mg}$, Thai Sarpunti $1373.9 \pm 5.32 \mathrm{mg}$. K rich fishes are Taki $501.47 \pm 2.9 \mathrm{mg}$, Coral 415.24 $\pm 2.8 \mathrm{mg}$ and $\mathrm{Na}$ rich fishes are Thai Sarpunti 780.01 \pm 3.8 , Ganges Chapila $415.32 \pm 2.34 \mathrm{mg}$, Loitta $497.38 \pm 4.21 \mathrm{mg}$. Trace mineral, $\mathrm{Mg}$ is high in Coral $187.98 \pm 0.61 \mathrm{mg}$, Punti $148.16 \pm 0.62 \mathrm{mg}$, Datina $144.05 \pm 0.35 \mathrm{mg}$, Kachki $143.49 \pm 0.3 \mathrm{mg}$ fishes, whereas $\mathrm{Fe}$ are high in Chapila $15.95 \pm 0.03 \mathrm{mg}$, Punti $10.31 \pm 0.2$, Poa 7.01 \pm 0.66 and $\mathrm{Zn}$ in Thai Sarpunti $40.20 \pm 0.34 \mathrm{mg}$, Poa 29.32 $\pm 0.32 \mathrm{mg}$ fishes. Considering $\mathrm{Mn}$, Chapila $6.34 \pm 0.04 \mathrm{mg}$ is the highest. This study indicate that small fishes with bones are important source of essential minerals especially $\mathrm{Ca}$. Culture species found to be rich in source of protein, energy and lipids. Marine species exhibit good combination of protein and minerals. This study also encourage to take a culture species like Thai Sarpunti (Barbonymus gonionotus) for its high nutritional meat values and also to consume marine fishes and small fishes with bones for better nourishment. Promotion of the production and consumption of small fishes therefore be encouraged for better nutritional achievement.
\end{abstract}

Key words: Small indigenous species (SIS), marine fish, proximate, mineral composition.

\section{INTRODUCTION}

Bangladesh is dominated by floodplains and rivers which are rich ecosystems for diverse freshwater fauna. The biologically rich open water bodies include 264 species of inland fish (Rahman 2005) of which 140 species have been identified as small indigenous species (SIS) (Felts and Ahmed 1997). Small Indigenous Fish Species (SIS) defined as species attaining a maximum length of $25 \mathrm{~cm}$ (Roos et al. 2003). Marine water of Bangladesh also having 442 species of fish and 36

*Author for correspondence: <mnnaser@du.ac.bd>. 1Department of Zoology, Faculty of Biological Sciences, University of Dhaka, Bangladesh. 
species of marine shrimps (Quader 2010). Aquaculture have been practiced largely in Bangladesh from early 1990. In the past SIS were regarded as weed fish and eradicated from the fish culture pond. The drastic reduction of small fish in the natural sources, have given focus to the necessity of culture and conservation of SIS (Wahab 2003). Bangladesh is one of the world's leading inland fisheries producer with a production of 10,54,585 MT during 2010-11, with marine catch total of 5,46,333 MT and a total production from aquaculture of $14,60,769$ MT. Fisheries sector contributed $4.43 \%$ to national GDP and $22.21 \%$ to the agricultural GDP and $2.73 \%$ to foreign exchange earnings by exporting fish products in 2010-11 (DoF 2014). In low income countries like Bangladesh, small fish are only consumed protein sources, as they are accessible, less expensive, affordable well liked, culturally acceptable and can be purchased in small quantities (Roos et al. 2003). Fish account for $60 \%$ of the animal protein consumed by the population and also provide essential vitamins, minerals and fatty acids (Hoq et al. 2011). Small fish plays an important role in the everyday diet of Bangladesh, which are eaten along with the main staple dishes. This moment the average fish consumption is $60 \mathrm{~g} /$ day/person (DoF 2014). SIS have been considered as an important source of macro and micro nutrients that can play an important role in eliminating malnutrition in the country (Ahmad and Hassan 1983). The main objective of this research is to determine the proximate and mineral composition of commonly available fishes for inhabitants and to understand the nutritional values among freshwater small fishes, culture and marine water fishes of Bangladesh.

\section{MATERIAL AND METHODS}

This study was conducted from June 2012 to April 2013 at the Institute of Food Science and Technology (IFST), BCSIR Laboratories Dhaka, Bangladesh. Fishes were collected from three local markets, which included Mohammadpur Town Hall Kacha Bazar, Kawran Bazar and Jatrabari Fish Market Dhaka, Bangladesh.

Eighteen locally available fish species were collected for this study. Fish species were selected according to their availability, accessibility and demand of consumers in the marketplaces. Eight freshwater small Indigenous fishes were Mola (Amblypharyngodon mola), Dhela (Rohtee cotio), Kachki (Corica soborna), Punti (Puntius sophore), Kajoli (Ailiichthys punctata), Chapila (Gudusia chapra), Ganges Chapila (Gonialosa manmina), Taki (Channa punctatus). Five freshwater culture fishes were Tilapia (Oreochromis niloticus), Thai Sarpunti (Barbonymus gonionotus), Tatkini (Crossocheilus latius), Rui (Labeo rohita) and Thai Pangus (Pangasianodon hypophthalmus). Five Estuarine and Marine fish species were Coral (Lates calcarifer), Datina (Pomadasys argenteus), Poa (Otolithoides pama), 
Loitta (Harpadon nehereus) and Chanda (Pampus argenteus). Identification was done after Rahman (2005), Shafi and Quddus (1982) and Quddus and Shafi (1983).

Approximately $1.0-1.5 \mathrm{~kg}$ fish of consuming size of each variety were collected. The fish samples were brought to lab quickly to avoid any spoilage during transportation. Ice box was used during collection of fish from the peripheral points. Taking the sample in lab, it was cleaned and processed for edible portion. Small fish was taken as a whole. Raw whole fish were taken; head, jaw, eye, gill, flesh, bones and viscera.

Collected fishes were then rapidly processed for estimation of moisture content. The dried samples were used for analysis of Proximate and Mineral contents. Proximate composition was determined by following protocol of the Association of Official Analytical Chemists (AOAC, 2005) procedures. Determination of proximate composition; Moisture (Oven Drying Method), Protein (Micro-kjeldahl method), Fat (Cold Method), Ash (Gravimetric Method) and mineral composition were Calcium (Ca), Potassium (K), Iron (Fe), Sodium $(\mathrm{Na})$, Magnesium $(\mathrm{Mg})$, Zinc $(\mathrm{Zn})$ and Manganese $(\mathrm{Mn})$ performed in triplicate.

Total Carbohydrate and Energy were determined by following equation.

Total Carbohydrate : 100 - (Moisture + Protein + Fat + Ash)

Energy: (4 X Total Carbohydrate) $+(4$ X Protein $)+($ Fat X 9)

Minerals solution was prepared by Nitric Acid $\left(\mathrm{HNO}_{3}\right)$ and Hydrogen per Oxide $\left(\mathrm{H}_{2} \mathrm{O}_{2}\right)$ digestion by using Microwave Digester (Model: Berghof Speed Wave). Mineral composition was determined by Atomic Absorption Spectrophotometer (AAS) by Thermo Scientific, iCE 3000 Series, USA. All chemicals and reagents used in the analysis of the nutrient profile were of analytical grade and were purchased from Merck (Germany), BDH (UK), Sigma Chemical Co (St. Louis, MO, USA). Results showed in the tables are in (mean \pm SEM).

\section{RESULTS AND DISCUSSION}

The content of proximate and selected mineral composition of commonly consumed fishes is shown in Table 1. Based on the detail results of 18 popular fish species a distinct picture of nutrients of commonly consumed fishes are evident.

Moisture: Moisture content of small indigenous fish species (SIS) ranged from 75- $81 \%$, culture fishes $69-79 \%$ and marine fishes $68-87 \%$. The highest percentage of moisture was found in marine species; Loitta $87.02 \pm 3.21 \%$ and lowest in Coral $68.68 \pm 3.49 \%$. 


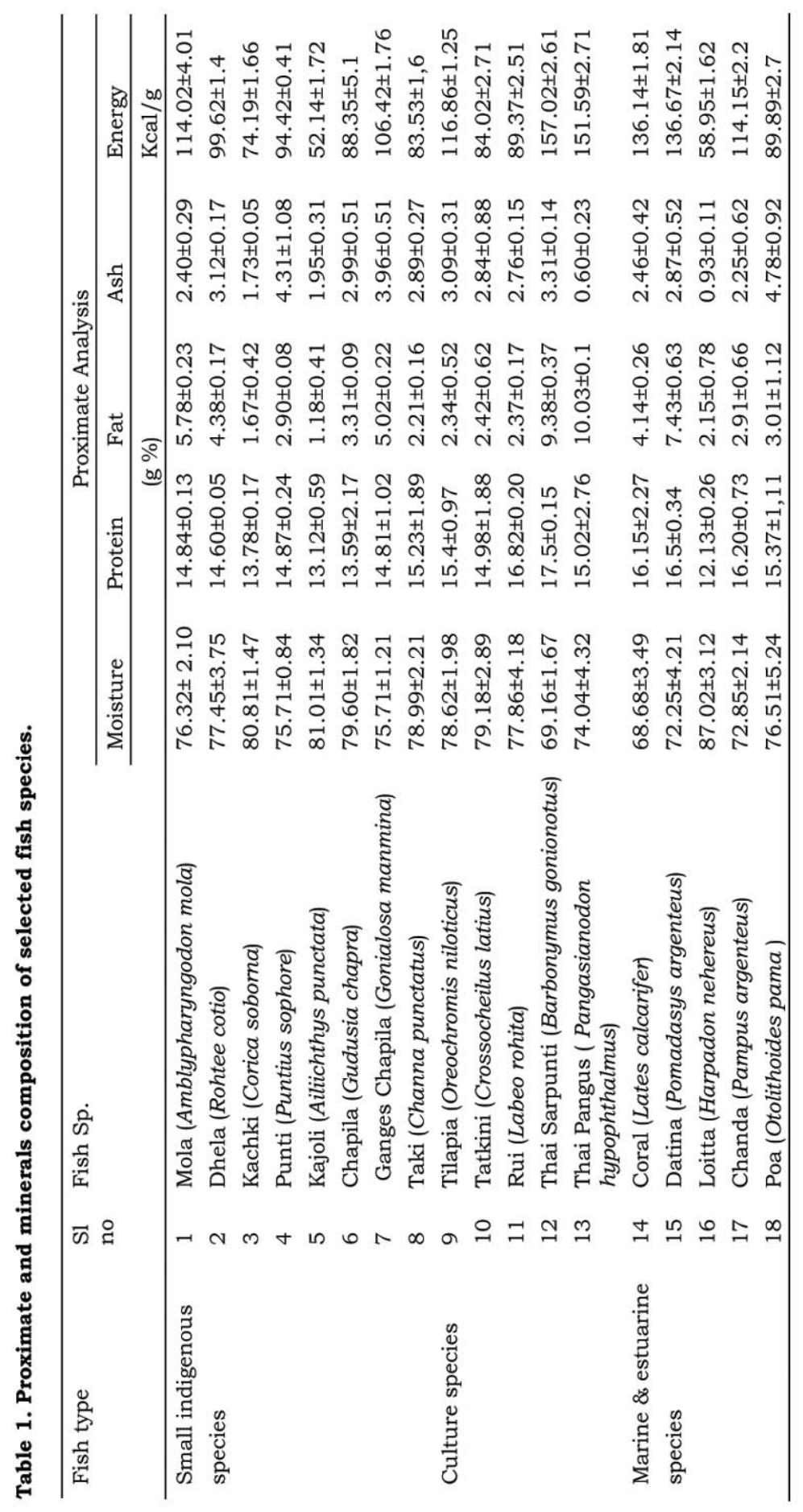




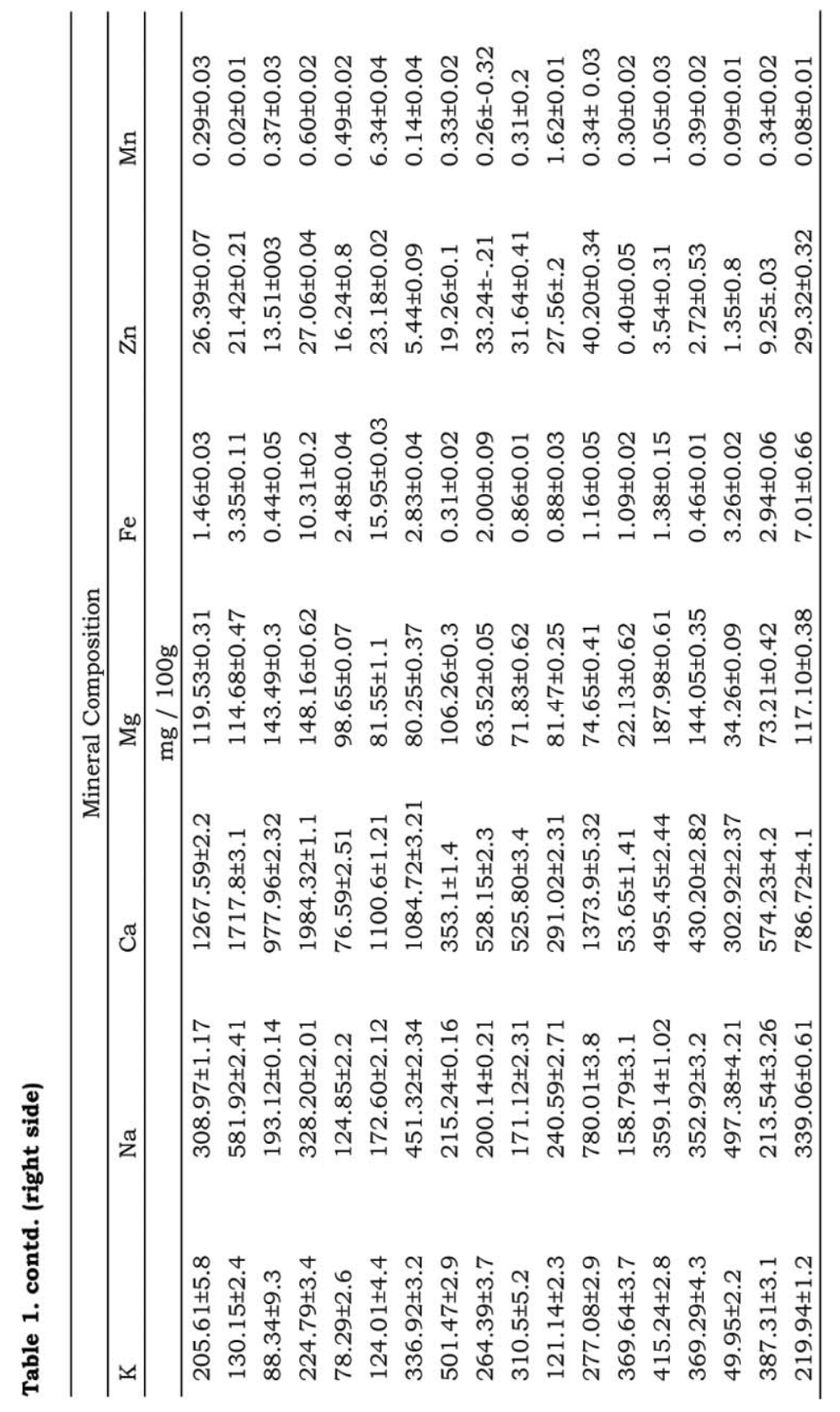


Ash: Ash content of SIS ranged from 1.95-4.31\%, culture fishes $0.60-3.31 \%$ and marine fishes $0.93-4.78 \%$. Ash content was highest in Poa $4.78 \pm 0.92 \%$ and lowest in Thai Pangus $0.60 \pm 0.23 \%$.Ash also found higher in freshwater Ganges Chapila 3.96 $\pm 0.51 \%$ and culture Thai Sarpunti $3.31 \pm 0.14 \%$.

Protein: Protein content of SIS ranged from 13- 15\%, culture fishes $14-17 \%$ and marine fishes $12-16 \%$. Protein was highest in Thai Sarpunti $17.5 \pm 0.15 \%$ and lowest in Loitta $12.13 \pm 0.26 \%$. Protein content of Culture and Marine fishes were higher than SIS fishes. Freshwater Rui $16.82 \pm 0.02 \%$ and Marine: Datina $16.5 \pm 0.34 \%$ and Chanda $16.20 \pm 0.73 \%$ also contain good amount of protein.

Fat: Fat content of SIS ranged from 1.18-5.78\%, culture fishes $2.34-10.03 \%$ and marine fishes 2.15-5.02\%. Fat content highest in Thai Pangus $10.03 \pm 0.1 \%$ and lowest in Kajoli $1.18 \pm 0.41 \%$. Fat content in Culture fish were comparatively higher than other species. Culture fishes Thai Sarpunti 9.38 $\pm 0.37 \%$; Marine fishes Datina $7.43 \pm 0.63 \%$ and Freshwater: Mola 5.78 $\pm 0.23 \%$, Dhela $4.38 \pm 0.17 \%$, Ganges Chapila $5.02 \pm 0.22 \%$ also contain a rich amount of fat.

Energy: Energy content of SIS ranged from 52.14-114.02 Kcal/g, culture fishes 84.02-157.02 Kcal/g and marine fishes 58.95-136.67 Kcal/g. Energy content found highest in Thai Sarpunti $157.02 \pm 2.61 \mathrm{Kcal} / \mathrm{g}$ and lowest in Kajoli $52.14 \pm 1.72 \mathrm{Kcal} / \mathrm{g}$. Energy found significantly higher in culture sp. Thai Sarpunti $157.02 \pm 2.61 \mathrm{Kcal} / \mathrm{g}$ and Thai Pangus $151.59 \pm 2.71 \mathrm{Kcal} / \mathrm{g}$ than Freshwater Mola $114.02 \pm 4.01 \mathrm{Kcal} / \mathrm{g}$; marine sp. Coral 136.14 $\pm 1.81 \mathrm{Kcal} / \mathrm{g}$, Datina $136.67 \pm 2.14 \mathrm{Kcal} / \mathrm{g}$ and Chanda $114.15 \pm 2.2 \mathrm{Kcal} / \mathrm{g}$.

Potassium content of SIS ranged from 78.29-501.47 mg, culture fishes 121.14-369.64 $\mathrm{mg}$ and marine fishes 49.95-415.24 mg. In $100 \mathrm{~g}$ minerals, potassium found significantly rich in Taki $501.47 \pm 2.9 \mathrm{mg}$, Coral 415.24 \pm 2.8 $\mathrm{mg}$ and lowest in Loitta $49.95 \pm 2.2 \mathrm{mg}$. Potassium found significantly high in freshwater SIS Mola 205.61 $\pm 5.8 \mathrm{mg}$, Pu nti 224.79 $\pm 3.4 \mathrm{mg}$, Ganges Chapila $336.92 \pm 3.2 \mathrm{mg} ; \quad$ in culture sp. Tatkini $310.5 \pm 5.2 \mathrm{mg}$, Thai SarPunti 277.08 $\pm 2.9 \mathrm{mg}$, Thai Pangus 369.64 \pm 3.7 ; in marine fishes Datina 369.29 \pm 4.3 $\mathrm{mg}$, Chanda $387.31 \pm 3.1 \mathrm{mg}$, Poa $219.94 \pm 1.2 \mathrm{mg}$.

Sodium content of SIS ranged from 124.85-581.92 mg, culture sp. 158.79$780.01 \mathrm{mg}$ and marine sp. 213.54-497.38 mg. Sodium was highest in Culture sp. Thai Sarpunti $780.01 \pm 3.8$ and lowest in Kajoli $124.85 \pm 2.2$ mg. Sodium found significantly high in freshwater SIS Ganges Chapila $415.32 \pm 2.34 \mathrm{mg}$, Punti 328.20 $\pm 2.01 \mathrm{mg}$, Mola 308.97 $\pm 1.17 \mathrm{mg}$; in marine fishes Coral 359.14 \pm 1.02 $\mathrm{mg}$, Loitta $497.38 \pm 4.21 \mathrm{mg}$.

Calcium: Calcium content of SIS ranged from 76.59-1984.32 mg, culture fishes 53.65-1373.9 $\mathrm{mg}$ and marine fishes 302.92-1084.72 mg. Calcium content was highest in Punti $1984.32 \pm 1.1 \mathrm{mg}$ and lowest in Thai Pangus $53.65 \pm$ 
$1.41 \mathrm{mg}$. Calcium content found significantly high in freshwater SIS Mola $1267 \pm 2.2 \mathrm{mg}$, Dhela1717.8 $\pm 3.1 \mathrm{mg}$, Ganges Chapila1084.72 $\pm 3.21 \mathrm{mg}$, Kachki $977.96 \pm 2.32 \mathrm{mg}$, Chapila $1100.6 \pm 1.21 \mathrm{mg}$; in culture sp. Thai Sarpunti 1373.9 $\pm 5.32 \mathrm{mg}$; in marine fishes Poa $786.72 \pm 4.1 \mathrm{mg}$.

Magnesium of SIS ranged from 81.55-148.16 mg, culture fishes 22.13-81.47 $\mathrm{mg}$ and marine fishes 34.26-187.98 mg. Magnesium was highest in Coral $187.98 \pm 0.61 \mathrm{mg}$ and lowest in Thai Pangus $22.13 \pm 0.62 \mathrm{mg}$. Magnesium found significantly high in freshwater SIS Mola $119.53 \pm 0.31 \mathrm{mg}$, Dhela $114.68 \pm 0.47 \mathrm{mg}$, Punti 148.16 $\pm 0.62 \mathrm{mg}$, Kachki $143.49 \pm 0.3 \mathrm{mg}$; in marine fishes Coral $187.98 \pm 0.61 \mathrm{mg}$, Datina $144.05 \pm 0.35 \mathrm{mg}$, Poa $117.10 \pm 0.38 \mathrm{mg}$.

Iron of SIS ranged from 0.31-15.95 mg, culture fishes 0.86-2.0 $\mathrm{mg}$ and marine fishes $0.46-7.01 \mathrm{mg}$. Iron found significantly rich in SIS Chapila $15.95 \pm$

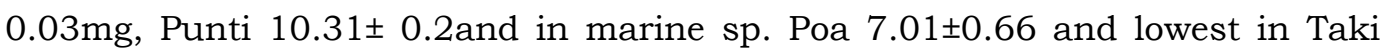
$0.31 \pm 0.02 \mathrm{mg}$.

Zinc of SIS ranged from $13.15-27.06 \mathrm{mg}$, culture fishes $0.40-40.20 \mathrm{mg}$ and marine fishes 1.35-29.32 mg. Zinc was highest in culture sp. Thai Sarpunti $40.20 \pm 0.34 \mathrm{mg}$ and lowest in culture sp. Thai Pangus $0.40 \pm 0.05 \mathrm{mg}$. Zinc found significantly rich in freshwater SIS and culture species and very poor amount in marine species exceptional is Poa $29.32 \pm 0.32 \mathrm{mg}$.

Manganese content of SIS ranged from 0.02-6.34 mg, culture fishes 0.26$1.62 \mathrm{mg}$ and marine fishes 0.08-1.05 mg. Mn was highest in Chapila 6.34 \pm 0.04 $\mathrm{mg}$ and lowest in Dhela $0.02 \pm 0.01 \mathrm{mg}$. Mn found in culture sp. Rui $1.62 \pm 0.01$ $\mathrm{mg}$ and in estuarine fishes Coral $1.05 \pm 0.03 \mathrm{mg}$ and others found below $1 \mathrm{mg}$.

Protein is a nutrient needed by the human body for growth and maintenance (Hermann 2014). Fish oil is one of the important natural sources of polyunsaturated fatty acid having eicosapentaenoic acid (EPA) and docosahexaenoic acid (DHA) which have been proven useful effect on human body (Saoud et al. 2008). According to NHS (2007) daily requirements of protein for human are $50 \mathrm{~g}$, total fat $65 \mathrm{~g}$ and total carbohydrate $300 \mathrm{~g}$. Approximately $4 \%$ of body's mass consists of minerals. Mineral helping in maintaining normal heart rhythm, muscle contractility, neural conductivity, acid base balance, help regulate cellular metabolism by becoming part of enzymes and hormones that modulate cellular activity (McArdle 2000). According to NHS direct online (2007) daily requirements of major minerals Ca $700 \mathrm{mg}$, Na $2400 \mathrm{mg}, \mathrm{K} 3500 \mathrm{mg}, \mathrm{Mg}$ $300 \mathrm{mg}, \mathrm{Mn}<0.5 \mathrm{mg}$ and trace mineral $\mathrm{Fe} 8.7 \mathrm{mg}, \mathrm{Zn} 9 \mathrm{mg}$. In view of the importance of minerals in human nutrition and specially the substantial quantities required for foetal growth, bones formation, teeth and muscle growth, intelligence, neural development in young children, milk production of lactating women (Larsen et al. 2000). 
Comparison of nutritional composition of studied fish samples it is evident that fishes are a good source of essential nutrients. The present work elucidated more on the importance of small indigenous fishes as rich source of minerals and has broadened our knowledge on the nutritional value difference of freshwater, culture and marine fish species. According to Stansby (1954) and Jacquot (1961) variation in nutrient composition of fish flesh may vary with species variation, season, age and the feeding habit of fish. This research revealed that SIS fish with bones may be an excellent source of important nutrients for human. Protein tended to be higher in culture and marine fishes. Fat exceptionally higher in culture species and marine fishes are a good combination of protein and minerals. Investigation also highlighting that a very common culture fish Thai Sarpunti is very rich in protein, energy and essential minerals $\mathrm{Na}, \mathrm{Ca}, \mathrm{Zn}, \mathrm{Mg}$. And also discouraged to take Thai Pangus which has very low food value. The knowledge of nutrient content of fishes is important now a days. From this study one can easily choose fishes for getting high protein, lipid and essential minerals supplement in the diet (Table 2).

Table 2. High nutrient contents of some common fishes of Bangladesh.

\begin{tabular}{lll}
\hline $\begin{array}{l}\text { High protein } \\
\text { groups }\end{array}$ & \multicolumn{1}{c}{ High lipid groups } & High mineral groups \\
\hline Thai Sarpunti, & Thai Sarpunti, Thai & Ca Rich Fishes: Punti, Mola, Dhela, Chapila, Kachki, \\
Rui, Coral, & Pangus, Chapila, & Thai Sarpunti, Poa. \\
Datina, & Datina, Mola, Dhela. & K Rich Fishes: Taki and all Marine sp. Chanda, \\
Chanda & & Datina, Coral. \\
& Na Rich Fishes: Thai SarPunti, Ganges Chapila, Dhela \\
& and Marine fishes Poa, Loitta, Coral. \\
& Mg Rich Fishes: Coral, Kachki, Punti, Mola, Dhela, \\
& Poa. \\
& Fe Rich Fishes: Chapila, Punti, Poa. \\
& Zn Rich Fishes: All SIS, Thai SarPunti, Rui, Tatkini, \\
& Chanda, Poa. \\
& Mn: Chapila \\
\hline
\end{tabular}

Thus efforts should be made to promote the production as well as consumption of SIS eaten whole, especially by pregnant-lactating women and young children in low income countries. Therefore it can be said that SIS can play significant role to fulfill the nutrient demand of the mother and child, even in case of malnourished and poorer section of the population. There is limited information on the nutritive value difference of fish species in Bangladesh. It is necessary to formulate guideline for common people to help them to plan better nutritional diet for good health. Further this knowledge should be provided to the mothers, children and the community at large for better nutrition supplement (FAO, WFO and IFAD 2012). The outcomes of this study will help in 
generating knowledge on nutritional security of Bangladesh and shall encourage the culture potential of small indigenous fishes.

\section{LITERATURE CITED}

AHMAD, K. and HASSAN, N. 1983. Nutrition Survey of Rural Bangladesh1981-82. Dhaka. Institute of Nutrition and Food Science, University of Dhaka. pp. 66.

AOAC. 2005. Official Methods of Analysis, $18^{\text {th }}$ ed. Association of Official Analytical Chemists, Gaithersburg, Maryland, USA.Ch 35, pp.1-2,8,11. Ch 39, pp. 6-8.

DoF 2014.Annual Fish Production of Bangladesh 2010-2014(online). Department of Fisheries, Ministry of Fisheries and Livestock, Government of People's Republic of Bangladesh, Dhaka, http://www.fisheries.gov.bd/node/14.

FELTS, R.A. and AHMED, K. 1997. Small Indigenous Fish Culture in Bangladesh. Proc. National workshop on small indigenous fish culture in Bangladesh. Rajshahi University, Rajshahi, pp.156

HERMANN, J. R. 2014. Protein and the Body. Oklahoma Cooperative Extension Service. Division of Agricultural Sciences and Natural Resources, Oklahoma State University. pp.T -3163:1-4.

HOQ, M.E., Islam, M.M., ALI, M.Z. and KHAN, M.M. 2011. Nutrient Composition of Small Indigenous Fish species (SIS) and Processed SIS of Bangladesh. Report of BFRI and BARC. 74p.

JACQUOT, R. 1961. Organic Constituents of Fish and Other Aquatic Animals: Fish as Food. Brogstorm academic press, NY and London. pp.145-209.

LARSEN T, THILSTED S. H., KONGSBAK K and HANSEN M. 2000. Whole small fish as a rich calcium source. British Journal of Nutrition, 83: 191-196.

McARDLE, W.D. 2000. Micronutrints and Water. $2^{\text {nd }}$ ed. Essentials of Exercise Physiology, USA: Lippincott Williams and Wilkins, pp. 75.

NHS Direct Online. 2007. Vitamins and Minerals [www] Available from: http:// www. nhs .uk/Conditions/vitamins-minerals/Pages/vitamins-minerals.aspx. Accessed on: 20.01.2013.

QUADER, O. 2010. Coastal and marine biodiversity of Bangladesh (Bay of Bengal) FB08. Proc of International Conference on Environmental Aspects of Bangladesh (ICEAB 10). Japan. Sept. pp 83-86.

QUDDUS, M.M.A. and SHAFI, M. 1983. Bangoposagorer Matsho Sampad (in Bengali). 2nd ed. Bangla Academy, Dhaka. pp-426.

RAHMAN, A.K. 2005. Freshwater Fishes of Bangladesh. $2^{\text {nd }}$ ed. Zoological Society of Bangladesh, Dhaka, Bangladesh. pp 394.

ROOS, N., ISLAM, M.M. and THILSTED, S.H. 2003. Small Indigenous Fish Species in Bangladesh: Contribution to Vitamin A, Calcium and Iron Intakes. American Society for Nutritional Sciences. pp 4021-4026.

SAOUD, K. C., BATAL, M., GHANAWI, J. and LEBBOS N. 2008. Seasonal evaluation of nutritional benefits of two fish species in the eastern Mediterranian Sea . Int. J. Food Sci Tech. 43(3): 538542.

SHAFI, M. and QUDDUS, M.M.A. 1982. Bangladesher Matsho Sampad (in Bengali). 1st ed. Bangla Academy, Dacca, pp. 426.

STANSBY, M.Z. 1954. Composition of certain species of freshwater fish. Food. Res. 19: 231-234.

WAHAB, M.A. 2003. Small Indigenous Fish Species of Bangladesh: Potentials for Culture and Conservation. Technical Proc. of BAU-ENRECA/DANIDA Workshop. BAU, 166 pp.

FAO, WFO and IFAD. 2012. The State of Food Insecurity in the world 2012. Economic growth is necessary but not sufficient to accelerate reduction of hunger and malnutrition, Rome, FAO. $60 \mathrm{p}$.

(Manuscript received on 11 May, 2014; revised on 27 August, 2014) 